\title{
A New Type of Defect in the Gene for Bilirubin Uridine 5'-Diphosphate-Glucuronosyltransferase in a Patient with Crigler-Najjar Syndrome Type I
}

\author{
SACHIKO AONO, YASUKAZU YAMADA, HIROOMI KEINO, YOSHIKO SASAOKA, \\ TSUNEO NAKAGAWA, SHOJU ONISHI, SHUNJI MIMURA, OSAMU KOIWAI, AND \\ HIROSHI SATO
}

\begin{abstract}
Departments of Perinatology [S.A., H.K.] and Genetics [Y.Y.J, Institute for Developmental Research, Aichi Prefecture Colony, Kasugai, Aichi 480-03, Japan; Department of Pediatrics, Okazaki Municipal Hospital, Okazaki, Aichi 444, Japan [Y.S., T.N.J; Department of Pediatrics, Kagawa Medical School, Kita, Kagawa 76107, Japan [S.O.]; Department of Pediatrics, Nagoya University School of Medicine, Nagoya, Aichi 466, Japan [S.M.]; Department of Biochemistry, Aichi Cancer Center Research Institute, Nagoya, Aichi 464, Japan [O.K.]; and Department of Biology, Shiga University of Medical Science, Otsu. Shiga 520-21. Japan [H.S.]
\end{abstract}

\begin{abstract}
Crigler-Najjar syndrome (CN) type I, which is characterized by the complete absence of bilirubin uridine 5'-diphosphate-glucuronosyltransferase (UGT) activity, is inherited as an autosomal recessive trait associated with unconjugated hyperbilirubinemia. Phenobarbital has no effect on the bilirubin concentration in the serum of patients with CN type I. Recently, cDNA for two human liver bilirubin UGT (UGT1A and UGT1D) were isolated, and their genetic organization was determined. The UGT1A (UGT1*1) and UGT1D (UGT1*4) genes each have a unique exon 1 , whereas exons $2-5$ are common to both genes. It has been predicted that some defect in the exons common to both genes is responsible for the absence of UGT1A and UGT1D activities in CN type $I$, and five cases with such a mutation have been reported. We describe here a new type of defect in the gene for bilirubin UGT in a patient with $\mathrm{CN}$ type I, namely, an abnormality in the exon 1 that is characteristic of the UGT1A gene. This mutation is a single nucleotide substitution, that is, $C$ is changed to $A$ at base position 840 in UGT1A cDNA, and this change results in a stop codon. Our patient is homozygous for the defect, and his nonconsanguineous parents and elder brother, who are clinically normal, are heterozygous for the defective allele. No mutation was detected in any exons of the UGT1D gene. Our results suggest that a homozygous nonsense or deletion mutation is detected not only in the exons common to UGT1A and UGT1D genes but also in unique exon 1 of UGT1A in CN type I. (Pediatr Res 35: 629-632, 1994)
\end{abstract}

\section{Abbreviations}

UGT, uridine 5'-diphosphate-glucuronosyltransferase $\mathrm{CN}$, Crigler-Najjar syndrome

PCR, polymerase chain reaction

The UGT (EC 2.4.1.17) form a family of membrane-bound zymes that catalyze the conjugation of endogenous substrates, $\mathrm{ch}$ as bilirubin, steroids, or xenobiotics, with uridine diphos-

Received October 7, 1993; accepted February 4, 1994

Correspondence: Dr. Sachiko Aono, Department of Perinatology, Institute for velopmental Research, Aichi Prefecture Colony, Kasugai, Aichi 480-03, Japan. Supported in part by Grants-in-Aid for Scientific Research from the Ministry of ucation. Science and Culture in Japan (No. 05670465 and No. 05670977). phate-glucuronic acid. Bilirubin UGT, one member of this family, is essential for the excretion of bilirubin, a toxic metabolite derived from hemoproteins, into the bile (1).

In 1952, Crigler and Najjar (2) described a syndrome, CN type I, that featured severe chronic nonhemolytic unconjugated hyperbilirubinemia. In such cases, no bilirubin UGT activity can be detected in hepatic cells $(3,4)$. The patients with $\mathrm{CN}$ type I may succumb to kernicterus during the neonatal period (5) unless treated with phototherapy, plasmapheresis, liver transplantation, or some combination. The syndrome is inherited as an autosomal recessive trait and is clinically manifested only in its homozygous state (6). Usually, bilirubin levels reach $342-855 \mu \mathrm{mol} / \mathrm{L}$ in the serum. Traces of unconjugated and monoconjugated bilirubins have been detected in the bile of some patients (6).

$\mathrm{CN}$ type II, which is also characterized by marked unconjugated hyperbilirubinemia, was identified by Arias (7) in 1962. Compared with the course of $\mathrm{CN}$ type I, the clinical course in $\mathrm{CN}$ type II is almost always benign (e.g. total bilirubin level in the serum, 137-342 $\mu \mathrm{mol} / \mathrm{L}$ ) because hepatic bilirubin UGT activity, although at a reduced level, can be detected.

A major distinction between types I and II of this disorder is as follows: in patients with $\mathrm{CN}$ type II, administration of phenobarbital results in enhanced excretion of the glucuronide conjugates of bilirubin in the bile (8), as well as abrupt decreases in serum bilirubin levels $(3,8)$, whereas no effect on the concentration of bilirubin in the serum is observed on administration of phenobarbital to patients with $\mathrm{CN}$ type I (3).

Nowadays, it is possible to analyze the genetic background of $\mathrm{CN}$ types I and II in molecular level. Ritter et al. (9) reported the isolation and characterization of cDNA for two human liver bilirubin UGT, UGT1A [UGT1*1 (10)] and UGTID [UGT1*4 (10)]. The UGT1A and UGT1D genes belong to the UGT1 locus (11), which is a complex of six overlapping transcriptional units and encodes at least six isoforms of UGT, including phenol UGT $(11,12)$. The mRNA for two bilirubin UGT, as well as those for the other four UGT, have a common $3^{\prime}$ terminal region composed of four exons (exons 2, 3, 4, and 5), whereas the 5' half of each is derived from exons 1 that are specific to each isoform $(11,12)$. These findings suggest that in $\mathrm{CN}$ type I a genetic defect exists in both UGT1A and UGT1D in the common exons of the two genes, whereas in $\mathrm{CN}$ type II a defect exists in either of the UGT1A and UGTID, that is to say, in the exon 1 of the UGT1A gene or in that of UGT1D gene or in a partial defect in exons 2, 3,4 , or 5 (13). Indeed, five cases of genetic mutation in the common exons of the UGT1A and UGT1D genes have been found in patients with $\mathrm{CN}$ type I $(12,14-16)$. 
We have analyzed the genetic background of a patient who was diagnosed as having $\mathrm{CN}$ type I on the basis of cardinal symptoms. Here we report the new type of mutation form in this patient, namely, a nonsense mutation in exon 1 of the UGT1A gene.

\section{MATERIALS AND METHODS}

Human subjects. Blood samples were collected from a 1-y-old male CN type I patient, his parents, elder brother, and two unrelated normal males for DNA analysis. The patient was born after a 40 -wk gestation, weighing $2752 \mathrm{~g}$, to clinically normal parents, whose total bilirubin levels in the serum were 21 and 17 $\mu \mathrm{mol} / \mathrm{L}$. According to the census register, the parents of the patient were nonconsanguineous. Jaundice appeared at $4 \mathrm{~d}$ of age, and the total bilirubin level in the serum was $359 \mu \mathrm{mol} / \mathrm{L}$. At $20 \mathrm{~d}$ of age, total and direct bilirubin levels were $530 \mu \mathrm{mol} / \mathrm{L}$ and $39 \mu \mathrm{mol} / \mathrm{L}$, respectively, so this patient received treatment in the hospital. The mother was $\mathrm{O}$ positive, and the child was $\mathrm{A}$ positive. Results for direct and indirect Coombs' tests were negative for both. Serum bilirubin levels were not lowered by administration of phenobarbital $(10 \mathrm{mg} / \mathrm{kg} / \mathrm{d})$ for $20 \mathrm{~d}$ from d 29 to 48 after birth, and no more than trace quantities of bilirubin conjugates were detectable by HPLC (17) in the blood and duodenal bile of the patient. Serum bilirubin levels in the father and mother of the patient were 21 and $17 \mu \mathrm{mol} / \mathrm{L}$, respectively.

Preparation of genomic DNA from lymphocytes. Genomic DNA was isolated from white blood cells by the method of Poncz et al. (18). The DNA, dissolved in $10 \mathrm{mM}$ Tris-HCl buffer (pH 7.5) that contained $1 \mathrm{mM}$ EDTA, was used as a template for PCR.

Amplification by PCR from genomic DNA. Four pairs of oligonucleotide primers for PCR (Table 1) and 16 primers for sequencing (Table 2) were designed by modifying the primers described by Bosma et al. (12). The unique exons 1 of the UGT $1 A$ and UGT1D genes and exon 5 were amplified separately by use of each pair of specific primers. Exons 2, 3, and 4 and the intervening introns were amplified simultaneously with the upstream primer of exon 2 and the downstream primer of exon 4 as described elsewhere (12).

PCR was performed by the method of Yamada et al. (19) with slight modification. Genomic DNA $(1.5 \mu \mathrm{g})$ was mixed with 1 $\mu \mathrm{M}$ of each primer and 2 IU of Taq DNA polymerase (AmpliTaq; Perkin-Elmer Cetus, Norwalk, CT) in a final vol of $0.1 \mathrm{~mL}$. Amplification was carried out for 37 cycles $\left(94^{\circ} \mathrm{C}, 1 \mathrm{~min} ; 55^{\circ} \mathrm{C}\right.$, $1 \mathrm{~min}$; and $72^{\circ} \mathrm{C}, 2 \mathrm{~min}$ ).

The sequences of the amplified DNA fragments were determined directly by use of the sequencing primers (Table 2). Only the synthesized DNA fragment corresponding to exon 1 of the UGT1D gene was subcloned into the pUC19 vector (BoehringerMannheim, Mannheim, Germany) and sequenced. To exclude the effects of PCR errors, we determined the DNA sequences of nine clones.

DNA sequencing. Direct sequencing of DNA was performed by the method of Yamada et al. (19). The pUC recombinants were sequenced by the standard protocols provided with Sequenase 2.0 (United States Biochemical Co., Cleveland, OH). Nucleotide sequences were recorded on a personal computer and analyzed with GENETYX, version 8.0, gene analysis software (Software Development Co., Tokyo, Japan).

\section{RESULTS}

Identification of mutation in UGT genes. We determined the DNA sequence of all the exons in the UGT1A and UGT1D genes. DNA analysis of exons 2, 3, 4, and 5 and of their flanking regions in the patient revealed no abnormal sequences, point mutations, or deletions as compared with the sequences for the normal controls (data not shown) and the published cDNA sequences (9). However, direct determination of the DNA sequence of exon 1 of the UGT1A gene revealed that the patient was homozygous for a single nucleotide substitution of $\mathrm{C}$ by $\mathrm{A}$ at position 840 (9) in UGT1A cDNA (Fig. 1). The observed point mutation $(\mathrm{C} \rightarrow \mathrm{A}$ ) changes the codon for cysteine at amino acid position 280 to a stop codon (TGA). We performed further analysis of the DNA sequence of exon 1 in the gene for the UGT1D for our patient, but no other mutation was detected.

Familial genetic analysis. The DNA sequence of exon 1 in the UGT1A gene was determined for each member of the patient's family. His parents (Fig. 1) and elder brother (not shown) were found to be heterozygous with respect to the mutation at base position 840 .

\section{DISCUSSION}

From the clinical symptoms, such as severe unconjugated hyperbilirubinemia, trace levels of bilirubin glucuronides in the bile, and the absence of any effect on the total bilirubin level in the serum of the administration of phenobarbital, our patient was diagnosed as having $\mathrm{CN}$ type $\mathrm{I}$.

We expected that a mutation would be detected in the common exons of the UGT1A and UGT1D genes, as found in other cases. Ritter et al. (14), Bosma et al. (12), and Moghrabi et al. (15) found a deletion of 13 nucleotides in exon 2 and a point mutation (at base position 1069 or 1021 of the UGT1A cDNA) that resulted in a stop codon in exon 3 , respectively, in their patients with CN type I. Bosma et al. (16) also reported two patients with a missense mutation in exon 4 and with a nonsense mutation in exon 2, respectively. Moreover, in the hyperbilirubinemic Gunn rat (20), a model for CN type I (21), a -1 frame shift mutation in the common $3^{\prime}$ termini of cDNA for both bilirubin UGT (22) and phenol UGT (23) has been reported (24-26). However, our patient with CN type I has a nonsense mutation in the unique exon 1 of the UGT IA gene for bilirubin UGT protein, which is constitutively expressed (Fig. 1). This is the first case of the identification of a mutation other than a mutation in the common exons (exons 2-5) of UGT genes in a case of CN type I.

It has been recognized that, among patients with $\mathrm{CN}$ type $\mathrm{I}$, some show a reduction in UGT activity toward phenolic sub-

Table 1. Oligonucleotide primers for amplification of all exons of the UGTIA and UGTID genes*

\begin{tabular}{|c|c|c|c|}
\hline \multirow[b]{2}{*}{ Exon } & \multicolumn{3}{|c|}{ Primer } \\
\hline & Name & Nucleotide sequence & \\
\hline 1 & BIEIA & 5'-AGG AGC AAA GGC GCC-3' & $F$ \\
\hline (UGT1A) & BIE1B & 5'-GCT TGC TCA GCA TAT ATC TGG G-3' & $\mathbf{R}$ \\
\hline & B2E1A & 5'-AGT CAG CTG TCG GTG GCT TCT G-3' & F \\
\hline (UGT1D) & B2E1B & 5'-CAT TGA TTG GAT GAA GGC ACC A-3' & $\mathbf{R}$ \\
\hline \multirow[t]{2}{*}{$2-4$} & BE24A & 5'-CTC TAT CTC AAA CAC GCA TGC C-3' & $\mathrm{F}$ \\
\hline & BE24B & 5'-TTT TAT CAT GAA TGC CAT GAC C-3' & $\mathbf{R}$ \\
\hline \multirow[t]{2}{*}{5} & BESA & 5'-GAG GAT TGT TCA TAC CAC AGG-3' & $F$ \\
\hline & BE5B & 5'-GCA CTC TGG GGC TGA TTA AT-3' & $\mathbf{R}$ \\
\hline
\end{tabular}

\footnotetext{
${ }^{*} \mathrm{~F}$, sense primer; $R$, antisense primer.
} 
Table 2. Oligonucleotide primers for sequencing of all exons of the UGTIA and UGTID genes*

\begin{tabular}{|c|c|c|c|}
\hline \multirow[b]{2}{*}{ Exon } & \multicolumn{3}{|c|}{ Primer } \\
\hline & Name & Nucleotide sequence & \\
\hline 1 & B1E11 & 5'-CTA TTT CAT GTC CCC TCT GC-3' & $\mathbf{R}$ \\
\hline \multirow[t]{4}{*}{ (UGT1A) } & B1E12 & 5'-GTC TTT TGT TAG TCT CGG GC-3' & $\mathbf{F}$ \\
\hline & B1E13 & $5^{\prime}$-TTG TTG TGC AGT AAG TGG GA-3' & $\mathbf{R}$ \\
\hline & BIE14 & 5'-CCA TTC TCC TAC GTG CCC AG-3' & $\mathrm{F}$ \\
\hline & B1E15 & 5'-AAG GGT TGC ATA CGG GGA ATA-3' & $\mathbf{R}$ \\
\hline 1 & B2E11 & $5^{\prime}$-ACC ACC AAC ACC TTT CCA CT-3' & $\mathbf{R}$ \\
\hline \multirow[t]{5}{*}{ (UGTID) } & $\mathrm{B} 2 \mathrm{E} 12$ & 5'-TTA CGC TGG GCT ACA CTC AAG-3' & $\mathrm{F}$ \\
\hline & B2E13 & 5'-CAG TAG CTC CAC ACA ACA CCT A-3' & $\mathbf{R}$ \\
\hline & B2E14 & 5'-CGA CCA ATT CAG ACC ACA TG-3' & $\mathrm{F}$ \\
\hline & B2E15 & 5'-ACT GAC ACC TCT CTC TGA AA-3' & $\mathbf{R}$ \\
\hline & B2E 16 & $5^{\prime}$-CAT CCG TGT GGC TGT TCC GA-3' & $\mathbf{F}$ \\
\hline 2 & BE241 & $5^{\prime}-$ GGA AGC TGG AAG TCT GGG-3' & $\mathbf{R}$ \\
\hline \multirow[t]{2}{*}{3} & BE242 & 5'-CTA GTT AGT ATA GCA GAT-3' & $\mathrm{F}$ \\
\hline & BE243 & 5'-GCT GTG CTT AAG CCA TTT-3' & $\mathbf{R}$ \\
\hline 4 & BE244 & 5'-CAG CTG TGA AAC TCA GAG-3' & $\mathrm{F}$ \\
\hline 5 & BE51 & $5^{\prime}$-TGC TGA CAG TGG CCT TCA TC-3' & $\mathrm{F}$ \\
\hline
\end{tabular}

${ }^{*} \mathrm{~F}$, sense primer; $\mathrm{R}$, antisense primer.

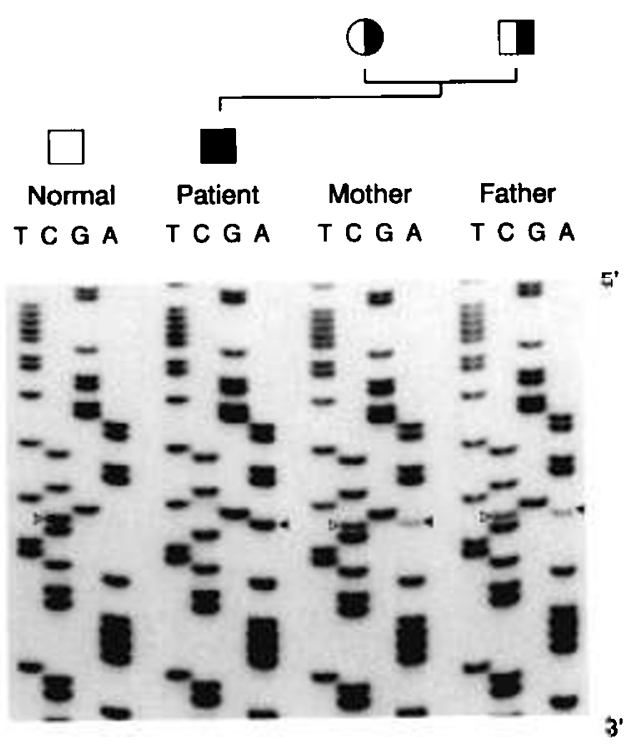

Normal TTI.GTT.GGT.GGA.ATC.AAC.TGČCTT.CAC Phe Val Gly Gly lle Asn Cys Leu His

Mutant TIT.GTI.GGT.GGA.ATC.AAC.TGÁ.CTT.CAC Phe Val Gly Gly lle Asn stop

Fig. 1. Nucleotide sequences of part of exon 1 of the UGT1A gene amplified from the genomic DNA of a control, a patient with CN type $\mathrm{I}$, and his parents. The mutation, a single nucleotide substitution of $\mathrm{C}$ $(\nabla)$ by $A(\nabla)$ at base position 840 in UGT 1A cDNA, generates a stop codon. The nucleotide position refers to the position in the previously reported sequence of UGTIA cDNA (8).

strates, as expected, but some have normal enzymatic activity in this respect (27). This observation indicates that some patients with CN type I have some defect in the exons 1 characteristic of each isoforms of UGT, in addition to patients with a mutation in the common exons. In this study, we confirmed this possibility by analyzing the DNA sequences of the UGT1A and UGT1D genes of a 1-y-old male.

Predictably, the UGT1A protein of our patient lacks the carboxyl-terminal 253 amino acids of the wild-type protein as a result of the point mutation and is completely, or almost completely, devoid of UGTIA enzymic activity. The origin of the trace amounts of conjugated bilirubin detected in bile and serum of the patient is presently unknown. Also puzzling is why the UGTID gene, which was apparently normal, was unable to provide enough enzyme to catalyze formation of significant amounts of bilirubin conjugates, particularly after phenobarbital treatment.

On the other hand, Bosma et al. (28) described unexpected findings that patients with $\mathrm{CN}$ type II had a mutation not only in exon 1 of the UGT1A but also in exon 1 of the UGT1D, which is consistent with the report of Aono et al. (29). On the basis of the study of the kindred, Bosma et al. (28) suggest that UGTID do not significantly contribute to the physiologic disposition of bilirubin. Our result that only the defect in the exon 1 of the UGT1A gene is responsible for CN type I may be consistent with their notion.

Acknowledgments. The authors thank Dr. N. Ogasawara, the director of the Institute for Developmental Research, Dr. A. Oohira of the Department of Perinatology, Institute for Developmental Research, and Dr. T. Yazawa of Department of Pediatrics, Okazaki Municipal Hospital, for encouragement in this work. We are deeply indebted to Dr. S. Itoh and Dr. K. Isobe of Department of Pediatrics, Kagawa Medical School, for bilirubin measurement by HPLC, and to Dr. N. Muto and Dr. H. Keino of the Departments of Genetics and Morphology, Institute for Developmental Research, for their helpful advice.

\section{REFERENCES}

1. Fevery J, Van Hees GP, Leroy P, Compernolle F. Heirwegh KPM 1971 Excretion in dog bile of glucose and xylose conjugates of bilirubin. Biochem J 125:803-810

2. Crigler Jr, JF, Najjar VA 1952 Congenital familial nonhemolytic jaundice with kernicterus. Pediatrics 10:169-180

3. Arias IM, Gartner LM, Cohen M, Ezzer JB, Levi AJ 1969 Chronic nonhemolytic unconjugated hyperbilirubinemia with glucuronyl transferase deficiency: clinical, biochemical, pharmacologic and genetic evidence for heterogeneity. Am J Med 47:395-409

4. Onishi S, Kawade N, Itoh S, Isobe K, Sugiyama S 1979 Postnatal development of uridine diphosphate glucuronyltransferase activity towards bilirubin and 2-aminophenol in human liver. Biochem J 184:705-707

5. Wolkoff AW, Roy-Chowdhury J, Gartner LA, Rose AL, Biempica L, Giblin DR, Fink D, Arias IM 1979 Crigler-Najiar syndrome (type I) in an adult male. Gastroenterology 76:840-848

6. Roy-Chowdhury J, Wolkoff AW, Arias IM 1982 Heme and bile pigment metabolism. In: Arias I, Popper H, Schachter D, Shafritz DA (eds) The Liver: Biology and Pathobiology. Raven Press, New York, pp 309-332

7. Arias IM 1962 Chronic unconjugated hyperbilirubinemia without overt signs of hemolysis in adolescents and adults. J Clin Invest 41:2233-2245

8. Yaffe SJ, Levy G, Matsuzawa T, Baliah T 1966 Enhancement of glucuronideconjugating capacity in a hyperbilirubinemic infant due to apparent enzyme induction by phenobarbital. N Engl J Med 275:1461-1466

9. Ritter JK, Crawford JM, Owens IS 1991 Cloning of two human liver bilirubin UDP-glucuronosyltransferase cDNAs with expression in COS-1 cells. J Biol Chem 266:1043-1047

10. Burchell B, Nebert DW, Nelson DR, Bock KW, lyanagi T, Jansen PL, Lancet 
D, Mulder GJ, Roy-Chowdhury J, Siest TR, Tephly TR, Mackenzie PI 1991 The UDP glucuronosyltransferase gene superfamily: suggested nomenclature based on evolutionary divergence. DNA Cell Biol 10:487-494

11. Ritter JK, Chen F, Sheen YY, Tran HM, Kimura S, Yeatman MT, Owens IS 1992 A novel complex locus UGTI encodes human bilirubin, phenol, and other UDP-glucuronosyltransferase isozymes with identical carboxyl termini. J Biol Chem 267:3257-3261

12. Bosma PJ, Roy-Chowdhury N, Goldhoorn BG. Hofker MH, Oude Elferink RPJ, Jansen PLM, Roy-Chowdhury J 1992 Sequence of exons and the flanking regions of human bilirubin UDP-glucuronosyltransferase gene complex and identification of a genetic mutation in a patient with Crigler-Najjar syndrome, type I. Hepatology 15:941-947

13. Moghrabi N, Clarke DJ, Boxer M, Burchell B 1993 Identification of an A-to$G$ missense mutation in exon 2 of the UGT1 gene complex that causes Crigler-Najjar syndrome type 2. Genomics 18:171-173

14. Ritter JK, Yeatman MT, Ferreira P, Owens IS 1992 Identification of a genetic alteration in the code for bilirubin UDP-glucuronosyl transferase in the $U D T I$ gene complex of a Crigler-Najjar type I patient. J Clin Invest 90:150155

15. Moghrabi N, Clarke DJ, Burchell B, Boxer M 1993 Cosegregation of intragenic markers with a novel mutation that causes Crigler-Najjar syndrome type implication in carrier detection and prenatal diagnosis. Am J Hum Genet 53:722-729

16. Bosma PJ, Roy-Chowdhury J, Huang T, Lahiri P, Oude Elferink RPJ, Van Es HHG, Lederstein M, Whitington PF, Jansen PLM, Roy-Chowdhury N 1992 Mechanisms of inherited deficiencies of multiple UDP-glucuronosyltransferase isoforms in two patients with Crigler-Najjar syndrome, type 1. FASEB J 6:2859-2863

17. Onishi S, Itoh S, Kawade N, Isobe K, Sugiyama S 1980 An accurate and sensitive analysis by high-pressure liquid chromatography of conjugated and unconjugated bilirubin IX- $\alpha$ in various biological fluids. Biochem J 185:281 284

18. Poncz M, Solowiejczyk D, Harpel B, Mory Y, Schwartz E, Surrey S 1982 Construction of human gene libraries from small amounts of peripheral blood: analysis of $\beta$-like globin genes. Hemoglobin 6:27-36

19. Yamada Y, Goto H, Suzumori K, Adachi R, Ogasawara N 1992 Molecular analysis of five independent Japanese mutant genes responsible for hypoxan- thine guanine phosphoribosyltransferase (HPRT) deficiency. Human Genet 90:379-384

20. Gunn CK 1938 Hereditary acholuric jaundice in a new mutant strain of rats J Hered 29:137-139

21. Schmid R, Axelrod J, Hammaker L, Swarm RL 1958 Congenital jaundice in rats, due to a defect in glucuronide formation. J Clin Invest $37: 1123-1130$

22. Sato H, Koiwai O, Tanabe K, Kashiwamata $S 1990$ Isolation and sequencing of rat liver bilirubin UDP-glucuronosyltransferase cDNA: possible alternate splicing of a common primary transcript. Biochem Biophys Res Commun 169:260-264

23. Iyanagi T, Haniu M, Sogawa K, Fujii-Kuriyama Y, Watanabe S, Shively JE, Anan KF 1986 Cloning and characterization of cDNA encoding 3-methylcholanthrene inducible rat mRNA for UDP-glucuronosyl-transferase. J Biol Chem 261:15607-15614

24. Sato H, Aono S, Kashiwamata S, Koiwai O 1991 Genetic defect of bilirubin UDP-glucuronosyltransferase in the hyperbilirubinemic Gunn Biophys Res Commun 177:1161-1164

25. Roy-Chowdhury J, Huang T, Kesari K, Lederstein M, Arias IM, Roy-Chowdhury N 1991 Molecular basis for the lack of bilirubin-specific and methylcholanthrene-inducible UDP-glucuronosyl transferase activities in Gunn rats. J Biol Chem 266:18294-18298

26. lyanagi T, Watanabe T, Uchiyama Y 1989 The 3-methylcholanthrene-inducible UDP-glucuronosyltransferase deficiency in the hyperbilirubinemic rat (Gunn rat) is caused by a -1 frameshift mutation. J Biol Chem $264: 21302$ 21307

27. Van Es HHG, Goldhoorn BG, Paul-Abrahamse M, Oude Elferink RPJ, Jansen PLM 1990 Immunochemical analysis of uridine diphosphate-glucuronosyltransferase in four patients with the Crigler-Najjar syndrome type I. J Clin Invest 85:1199-1205

28. Bosma PJ, Goldhoorn B, Oude Elferink RPJ, Sinaasappel M, Oostra BA Jansen PLM 1993 A mutation in bilirubin uridine 5'-diphosphate-glucuronosyltransferase isoform 1 causing Crigler-Najjar syndrome type II. Gastroenterology 105:216-220

29. Aono S, Yamada Y, Keino H, Hanada N, Nakagawa T, Sasaoka Y, Yazawa T. Sato H, Koiwai O 1993 Identification of defect in the genes for bilirubin UDP-glucuronosyltransferase in a patient with Crigler-Najjar syndrome type II. Biochem Biophys Res Commun 197:1239-1244 